\title{
Short Communication \\ Plant growth-promoting properties of cultivable endophytic root nodule bacterial isolates from Acacia mangium Willd
}

\section{Fatin Syafikah Ismail1, Masnindah Malahubban', Mohammad Hailmi Sajili² and Zakry Fitri Ab. Aziz ${ }^{1 *}$}

1Faculty of Agriculture and Food Sciences, Universiti Putra Malaysia Bintulu Sarawak

Campus, 97008 Bintulu, Sarawak, Malaysia

${ }^{2}$ Faculty of Bioresources and Food Industry, Universiti Sultan Zainal Abidin, Besut Campus, 22200 Besut, Terengganu, Malaysia

*Corresponding author email: zakryfitri@upm.edu.my

The present study was conducted to isolate and characterize endophytic bacteria isolated from root nodules of Acacia mangium Willd and subsequently tested for plant growth promotion. A total of five bacterial isolates were successfully isolated and subjected to morphological and biochemical examination. The present study found that all isolates had almost similar morphologically but differed in growth rate. All isolates were negative on $\mathrm{N}$-free and IAA tests, though positive on $\mathrm{P}$ solubilisation test. The present study demonstrated that the inoculation with isolate FSI3 had significantly improved $(p<0.05)$ root and shoot dry weight of winged bean seedlings as compared to uninoculated control. However, the inoculation did not significantly alter $(p>0.05)$ root and shoot length of winged bean seedlings. The present study suggests that the stimulatory effect by isolate FSI3 may be associated with P-solubilizing ability. A further test on isolate FSI3 is considered essential in future to uncover the several other possible plant growth-promoting mechanisms.

Keywords: Acacia mangium, endophytic bacteria, inoculation, root nodule

Acacia mangium Willd. is a productive nitrogen-fixing legume tree. $A$. mangium is often nodulated by rhizobia for symbiotic biological $\mathrm{N}_{2}$ fixation process. Rhizobia have a beneficial effect on the growth of legumes with their capacity to establish a symbiosis with legumes. Rhizobia inhabit root nodules and reduce the atmospheric nitrogen and make it in an available form to plants. Besides rhizobia group which are mostly dominated in root nodules of leguminous plants, there are also several other groups of bacteria that are also colonizing root nodules such as Agrobacterium and Pseudomonas species (Saïdi et al., 2013) and commonly known as endophytic bacteria. The interaction between endophytic bacteria and their host plants is not completely understood. However, many isolates seem to have beneficial effects on their hosts (Ulrich et al., 2008). These beneficial effects include promoting host growth and biological control of phytopathogens (Hallmann et al., 1997). Therefore, the objective of this study was to isolate the cultivable endophytic bacteria from the root nodules of Acacia mangium Willd and characterize them for plant growth-promoting traits.

Nodules were collected from Acacia mangium Willd. roots at Universiti Putra Malaysia Bintulu Sarawak Campus. A. mangium nodulated roots were washed thoroughly to remove soil and dirt. Healthy 
and large pink colour nodules were picked then washed thoroughly for several times with sterile distilled water. Subsequently, the nodules were immersed in $5.25 \%$ sodium hypochlorite for about four min. The nodules were surface sterilized in $95 \%$ alcohol for about three min. Then nodules were washed five times with sterile distilled water by gently swirl for about one min. Surface-sterilised nodules were crushed with sterile glass rod and streaked onto Yeast Extract Mannitol Agar (YEMA) medium. YEMA medium contained $(\mathrm{g} / \mathrm{l})$ : yeast extract: $1 \mathrm{~g}$; mannitol: $10 \mathrm{~g} ; \mathrm{K}_{2} \mathrm{HPO}_{4}$ : 0.5g; $\mathrm{MgSO}_{4} .7 \mathrm{H}_{2} \mathrm{O}: \quad 0.2 \mathrm{~g} ; \quad \mathrm{NaCl}: 0.1 \mathrm{~g}$; $\mathrm{CaCO}_{3}: 3 \mathrm{~g}$; bacto agar: $15 \mathrm{~g}, \mathrm{pH}$ medium was adjusted to $\mathrm{pH}$ 6.8. The inoculated YEMA plates were incubated at $28-30^{\circ} \mathrm{C}$ for 3-5 days for culture growth. A single colony was transferred and streaked onto fresh YEMA plates to obtain pure culture colonies. The morphological observations were made by using the dissecting microscope. Subsequently, phenotypic characterization was carried out by conducting several differential staining such as Gram reaction, capsule stain, and endospore stain according to standard microbiological procedures.

Screening for plant growthpromoting traits was conducted by determining $\mathrm{N}_{2}$ fixing capacity, Psolubilizing, IAA producing activities, and plant bioassay. The isolates were inoculated on Burk's $\mathrm{N}$ free agar medium and incubated at $28^{\circ} \mathrm{C}$ for $48 \mathrm{~h}$ for qualitative evaluation of $\mathrm{N}_{2}$-fixing activity (Zakry et al., 2010).

P-solubilising activity was determined by spot inoculated the respective isolates on National Botanical Research Institute's Phosphate (NBRIP) agar medium incubated for 5 - 10 days at $28 \pm 2^{\circ} \mathrm{C}$. NBRIP agar medium contained (g/l): glucose: $10 \mathrm{~g}$; tricalcium phosphate: $10 \mathrm{~g} ; \mathrm{MgCl}_{2} .6 \mathrm{H}_{2} \mathrm{O}: 5 \mathrm{~g} ; \mathrm{MgSO}_{4} .7 \mathrm{H}_{2} \mathrm{O}: 0.25 \mathrm{~g}$; $\mathrm{KCl}: 0.2 \mathrm{~g}$; $\left(\mathrm{NH}_{4}\right)_{2} \mathrm{SO}_{4}$ : 0.1 ; bacto agar: $15 \mathrm{~g}$. The formation of clear zone indicates that the $\mathrm{P}$ solubilising activity is positive (Nautiyal, 1999).
Indole-3-Acetic Acid (IAA) activity was determined by centrifuged $72 \mathrm{~h}$ old cultures at $3000 \mathrm{rpm}$ for $30 \mathrm{~min}$. Subsequently, two $\mathrm{mL}$ of supernatant was mixed with two drops of $0.1 \mathrm{ml}$ orthophosphoric acid and $4 \mathrm{ml}$ of Salkowski reagent (the mixture $50 \mathrm{~mL}$ of $35 \%$ sulphuric acid, $\mathrm{H}_{2} \mathrm{SO}_{4}$ and $1 \mathrm{ml}$ of $5 \mathrm{M}$ Iron (III) chloride, $\mathrm{FeCl}_{3}$ solution). Then, the mixtures were incubated in the dark for 30 minutes. IAA production was indicated by the development of pink colour (Zakry et al., 2010).

Winged bean (Psophocarpus tetragonolobus) was chosen as the test plant to determine plant growth-promoting potential after inoculation. The winged bean seeds were soaked in $95 \%$ ethanol for $5 \mathrm{~min}$ and then soaked in $5.25 \%$ sodium hypochlorite for 30-60 min and followed by six times washed with sterile distilled water for surface sterilization prior seed inoculation. The inoculation treatments were as follows: Uninoculated control (soaked in sterile distilled water and served as control); Isolate FSI1; Isolate FSI2; Isolate FSI3; Isolate FSI4; and Isolate FSI5. Plant bioassay screening was established using growth pouch method. To help in breaking seed dormancy, the seeds were immersed in warm (about $40^{\circ} \mathrm{C}$ ) sterile distilled water for $2 \mathrm{~h}$. Subsequently, the seeds were placed in between two-layer tissue paper then moisten with sterile distilled water for germination. After nine days, the germinated seeds were undergone for inoculation. The inoculation was made by soaking the germinated seeds for 2 hours in respective bacterial inoculant, each isolate with more than $10^{8}$ colony-forming unit (CFU) per ml. Growth pouches were held upright. Each growth pouch contained two layers of paper towel. The two layers paper towel was exposed to UV light before inserted into growth pouch. The germinated seeds with respective treatments were transplanted into the growth pouches and arranged in completely randomised design with three replications under laboratory conditions. Daily monitoring and watering on planted 
growth pouches were conducted. After 26 days of inoculation, harvesting and data collection were conducted. Data collection were root length $(\mathrm{cm})$, root dry weight $(\mathrm{mg})$, shoot length $(\mathrm{cm})$, shoot dry weight (mg).

Data on plant growth parameters were analysed for variance and mean comparison was made by Duncan's Multiple Range Test at 95\% level of significance. The statistical analysis was conducted by using Statistical Analysis System (SAS) version 9.3.

The present study successfully isolated five endophytic bacteria from $A$. mangium root nodules. Isolate FSI3 showed the fastest growth character on YEMA medium followed by FSI1, FSI2, and FSI4. However, isolate FSI5 demonstrated the slowest growth in this medium (Table 1).

Based on visual observation of culture media, these fast-growing isolates produced abundant gum-like compound on YEMA medium. In the present study, all isolates were able to produce acid after green coloured YEMA medium turned into yellow. The present study indicated that all isolates were Gram negative. Most of the isolates showed positive on capsule and endospore tests, except, isolate FSI5 reacted negatively on both tests. According to Garrity et al. (2004), most of the root nodule endophytic bacteria are belong to Rhizobium genera as they were Gram negative and able to produce acid. The isolates showed promising only on phosphate solubilisation activity. However, all isolates were negative on $\mathrm{N}_{2}$ fixing and IAA producing activities. The isolates might be involved dependence or symbiotic interaction with the host plant, to induce mutual benefits. Some strains of an endophytic advocate for host specificity and involvement of a compatible host plant (Lugtenberg and Kamilova, 2009).

Table 1: Some morphological and biochemical properties of endophytic bacteria isolated from root nodules of Acacia mangium

\begin{tabular}{|c|c|c|c|c|c|c|c|c|}
\hline $\begin{array}{c}\text { Isolate } \\
\text { code }\end{array}$ & $\begin{array}{l}\text { Odour, } \\
\text { Colour }\end{array}$ & $\begin{array}{c}\text { Elevation, } \\
\text { Surface, } \\
\text { Margin }\end{array}$ & $\begin{array}{c}\text { Cell } \\
\text { shape }\end{array}$ & $\begin{array}{c}\text { Growth } \\
\text { rate }^{a}\end{array}$ & $\begin{array}{c}\text { Gram, } \\
\text { Capsule, } \\
\text { Endospore }\end{array}$ & $\begin{array}{c}\text { Grow on } \\
\text { N-free }\end{array}$ & $\begin{array}{c}\text { Solubilis } \\
\text { e P }\end{array}$ & IAA \\
\hline FSI1 & $\begin{array}{c}\text { Odourless, } \\
\text { yellow }\end{array}$ & $\begin{array}{c}\text { Raised, } \\
\text { Smooth } \\
\text { shiny, entire }\end{array}$ & Rod & Fast &,,-++ & - & + & - \\
\hline FSI2 & $\begin{array}{c}\text { Odourless, } \\
\text { yellow }\end{array}$ & $\begin{array}{c}\text { Raised, } \\
\text { Smooth } \\
\text { shiny, entire }\end{array}$ & Rod & Fast &,,-++ & - & + & - \\
\hline FSI3 & $\begin{array}{c}\text { Odourless, } \\
\text { yellow }\end{array}$ & $\begin{array}{c}\text { Raised, } \\
\text { Smooth } \\
\text { shiny, entire }\end{array}$ & Round & $\begin{array}{l}\text { Very } \\
\text { fast }\end{array}$ &,,-++ & - & + & - \\
\hline FSI4 & $\begin{array}{c}\text { Odourless, } \\
\text { yellow }\end{array}$ & $\begin{array}{c}\text { Raised, } \\
\text { Smooth } \\
\text { shiny, entire }\end{array}$ & Round & Fast &,,-++ & - & + & - \\
\hline FSI5 & $\begin{array}{c}\text { Odourless, } \\
\text { yellow }\end{array}$ & $\begin{array}{c}\text { Raised, } \\
\text { Smooth } \\
\text { shiny, entire }\end{array}$ & Round & Slow &,,--- & - & + & - \\
\hline
\end{tabular}

aVery fast colonies appeared after 24 hours incubation. Fast colonies appeared after 48 hours incubation. Slow colonies appeared after 72 hours incubation. + = positive; - = negative 
Table 2: Effects of inoculation with root nodule endophytic bacteria on the early growth of winged bean seedlings

\begin{tabular}{|c|c|c|c|c|}
\hline Treatments & $\begin{array}{c}\text { Root length } \\
\text { (cm) }\end{array}$ & $\begin{array}{c}\text { Root dry } \\
\text { weight } \mathbf{( m g )}\end{array}$ & $\begin{array}{c}\text { Shoot length } \\
\text { (cm) }\end{array}$ & $\begin{array}{c}\text { Shoot dry } \\
\text { weight } \mathbf{( m g})\end{array}$ \\
\hline Uninoculated & $65.7 \mathrm{a}$ & $32.0 \mathrm{~b}$ & $39.5 \mathrm{a}$ & $96.3 \mathrm{~b}$ \\
\hline FSI1 & $146.8 \mathrm{a}$ & $55.7 \mathrm{ab}$ & $61.0 \mathrm{a}$ & $224.7 \mathrm{a}$ \\
\hline FSI2 & $97.2 \mathrm{a}$ & $46.7 \mathrm{~b}$ & $51.7 \mathrm{a}$ & $110.7 \mathrm{~b}$ \\
\hline FSI3 & $118.2 \mathrm{a}$ & $66.3 \mathrm{a}$ & $68.2 \mathrm{a}$ & $248.7 \mathrm{a}$ \\
\hline FSI4 & $99.3 \mathrm{a}$ & $55.7 \mathrm{ab}$ & $72.9 \mathrm{a}$ & $220.3 \mathrm{a}$ \\
\hline FSI5 & $125.6 \mathrm{a}$ & $35.3 \mathrm{~b}$ & $63.8 \mathrm{a}$ & $160.3 \mathrm{ab}$ \\
\hline
\end{tabular}

Means sharing the same letter(s) do not differ significantly at $p<0.05$ according to Duncan's

Multiple Range Test (DMRT). Data from three replicates.

All isolates formed colonies with clear zones on NBRIP agar medium plates indicating that the isolates able to solubilize phosphate. The ability of bacteria to solubilize insoluble phosphate has been attributed to their capacity to reduce $\mathrm{pH}$ by the excretion of organic acids during the assimilation of ammonia (Gyaneshwar et al. 1999). The bacteria not only assimilate the element but also solubilize quantities in excess of their nutritional demands, thereby making it available for plants (Chen et al., 2006). Some rhizobial strains are able to solubilize organic and inorganic phosphates (Abd-Alla, 1994). In the present study, the ability of isolates to produce acid may not be associated with their ability to fix nitrogen, but may be involved in phosphate solubilisation.

In the present study, the effect of inoculation on early growth of winged bean seedlings have been evaluated as shown in Table 2. Results show that the winged bean seedlings was mostly not affected by endophytic bacterial inoculation as compared to uninoculated control. Except on some plant growth parameters which were affected significantly $(\mathrm{p}<0.05)$ by isolate FSI3 on root dry weight and shoot dry weight at $66 \mathrm{mg}$ and $249 \mathrm{mg}$, respectively, over uninoculated control at $32 \mathrm{mg}$ and $96 \mathrm{mg}$, respectively. Isolate FSI1 and FSI4 were also significantly improved $(p<0.05)$, only on shoot dry weight of winged bean seedlings at $225 \mathrm{mg}$ and 220 $\mathrm{mg}$, respectively, as compared to uninoculated winged bean seedlings at 96 mg.

Low to not performing endophytic bacteria on plant growth as demonstrated in this study might be related to the capacity of producing organic acids. According to Tunes et al. (2012), the presence of organic acids as acetic, propionic and butyric acids during germination substratum of wheat seeds have reduced seedling development, mainly by reducing the length of the radicles. Since present study using soilless culture medium for plant growth, the effect due to organic acids produced by isolates to plant development might be extensive. The slight improvement on root and shoot of winged bean seedlings as shown by isolate FSI3 may be indicates that the isolate FSI3 was able to produce low amount of organic acid or regulate the producing potential thus decreasing the negative impact of organic acids on the development of winged bean seedling.

Hariprasad and Niranjana (2009) stated that phosphate solubilisation potential has been related to the strains' ability to lower the $\mathrm{pH}$ of the surroundings, either by releasing organic acids or protons. Secretion of organic acids such as gluconic acid, oxalic acid, and citric acid can directly solubilize mineral phosphate as a result of anion exchange or indirectly chelate both Fe an $\mathrm{Al}$ ions associated with phosphate. Therefore, this leads suitable and conducive environment for the endophytic bacteriawinged bean interactions. 
In conclusion, all endophytic bacteria isolated from root nodule of Acacia mangium Willd were Gram negative with ability to solubilise phosphate and mostly able to form capsule and endospore. Isolate FSI3 was the most promising isolate after exhibited enhancement in root and shoot of winged bean seedlings. Therefore, isolate FSI3 has the potential to be established as a plant growth-promoting rhizobacterium and subsequently formulated as biofertilizer and biostimulant. Further tests may be important to uncover the other possible beneficial mechanisms used by isolate FSI3 in the plant growth enhancement.

\section{Acknowledgements}

The authors would like to thank Laboratory of Microbiology and Plant Pathology, Department of Crop Science, Faculty of Agriculture and Food Sciences, Universiti Putra Malaysia Bintulu Sarawak Campus for research facilities.

\section{References}

Abd-Alla, M.H. 1994. Use of organic phosphorus by Rhizobium leguminosarum biovarviceae phosphatases. Biol. Fert. Soils, 18(3): 216-218.

Chen, Y., Rekha, P., Arun, A., Shen, F., Lai, W.-A. and Young, C. 2006. Phosphate solubilizing bacteria from subtropical soil and their tricalcium phosphate solubilizing abilities. Appl. Soil Ecol., 34(1): 33-41.

Garrity, G.M., Bell, J.A. and Lilburn, T.G. 2004. Taxonomic outline of the prokaryotes. Bergey's Manual of Systematic Bacteriology. Springer, New York, Berlin, Heidelberg.

Gyaneshwar, P., Parekh, L., Archana, G., Poole, P., Collins, M., Hutson, R. and Kumar, G.N. 1999. Involvement of a phosphate starvation inducible glucose dehydrogenase in soil phosphate solubilization by Enterobacter asburiae. FEMS Microbiol. Lett., 171(2): 223-229.
Hallmann, J., Quadt-Hallmann, A., Mahaffee, W. and Kloepper, J. 1997. Bacterial endophytes in agricultural crops. Can. J. Microbiol., 43(10): 895-914.

Hariprasad, P. and Niranjana, S. 2009. Isolation and characterization of phosphate solubilizing rhizobacteria to improve plant health of tomato. Plant Soil, 316(1-2): 13-24.

Lugtenberg, B. and Kamilova, F. 2009. Plant-growth-promoting rhizobacteria. Ann. Rev. Microbiol., 63541-63556.

Nautiyal, C.S. 1999. An efficient microbiological growth medium for screening phosphate solubilizing microorganisms. FEMS Microbiol. Lett. 170(1): 265-270.

Saïdi, S., Chebil, S., Gtari, M. and Mhamdi, R. 2013. Characterization of root-nodule bacteria isolated from Vicia faba and selection of plant growth promoting isolates. World J. Microbiol. Biotechnol., 29(6): 1099-1106.

Tunes, L.M.de, Avelar, S.A.G., Barros, A.C.S.A., Pedroso, D.C., Muniz, M.F.B., and Menezes, N.L.de. 2012. Critical levels of organic acids on seed germination and seedling growth of wheat. Revista Brasileira de Sementes, 34(3): 366-372.

Ulrich, K., Ulrich, A. and Ewald, D. 2008. Diversity of endophytic bacterial communities in poplar grown under field conditions. FEMS Microbiol. Ecol., 63(2): 169-180.

Zakry, F.A.A., Halimi, M.S., Abdul Rahim, K.B., Osumanu, H.A., Wong, S.K., Franklin, R.K., Stephen, L.C.T., and Make, J. (2010). Isolation and plant growth-promoting properties of rhizobacterial diazotrophs from pepper vine (Piper nigrum L.). Malays. Appl. Biol. 39: 41-45. 